
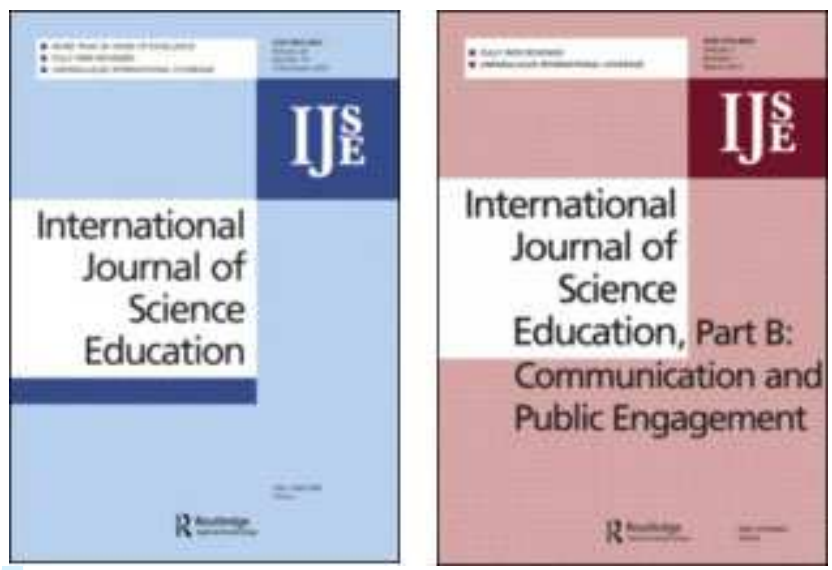

\title{
A Comparison of Student Teachers`Beliefs from Four Different Science Teaching Domains Using a Mixed Methods Design
}

\begin{tabular}{|r|l|}
\hline Journal: & International Journal of Science Education \\
\hline Manuscript ID: & TSED-2010-0164.R3 \\
\hline Manuscript Type: & Research Paper \\
\hline Keywords : & $\begin{array}{l}\text { Science Student Teachers`'Beliefs, Mixed Methods Approach, } \\
\text { Science Teacher Education }\end{array}$ \\
\hline Keywords (user): & \\
\hline \multicolumn{2}{|l}{} \\
\hline
\end{tabular}

\section{SCHOLARONE" Manuscripts}




\section{A Comparison of Student Teachers` Beliefs from Four Different Science Teaching} Domains Using a Mixed_Methods Design

\section{Abstract}

The study presented in this paper integrates data from four combined research studies, which are both qualitative and quantitative in nature. The studies describe freshman science student teachers` beliefs about teaching and learning. These freshmen intend to become teachers in Germany in one of four science teaching domains (secondary biology, chemistry and physics respectively, as well as primary school science). The qualitative data from the first study is based on student teachers' drawings of themselves in teaching situations. It was formulated using Grounded Theory to test three scales: beliefs about classroom organisation, beliefs about teaching objectives, and epistemological beliefs. Three further quantitative studies give insight into student teachers`curricular beliefs, their beliefs about the nature of science itself, and about the student- and/or teacher-centeredness of science teaching. This paper describes a design to integrate all these data within a Mixed Methods framework. The aim of the current study is to describe a broad, triangulated picture of freshman science student teachers` beliefs about teaching and learning within their respective science teaching domain. The study reveals clear tendencies between the sub-groups. The results suggest that freshman chemistry and - even more pronouncedly - freshman physics student teachers profess quite traditional beliefs about science teaching and learning. Biology and primary school student teachers express beliefs about their subjects which are more in line with modern educational theory. The Mixed Methods approach towards the student teachers beliefs is reflected upon and implications for science education and science teacher education are discussed.

Keywords: Science Student Teachers`Beliefs, Mixed Methods Approach, Science Teacher Education 


\section{Introduction}

In recent years, research evidence about students' learning of science has increasingly influenced educational reforms. The intentional aim was to more strongly promote studentactive and constructivist learning environments in science classrooms. Such reforms oriented themselves towards applicable knowledge learned within student-relevant contexts and achieving the objective of scientific literacy for all students (e.g. Valanides \& Angeli, 2002). On the other hand, research data on teachers' learning and professional development has shown that such educational reforms will only succeed if teachers` beliefs, their knowledge and attitudes are taken seriously into account and incorporated into the reform program (Clark and Peterson, 1986; Czerniak \& Lumpe, 1996; Nespor, 1987). The reason for this was stated by Bandura (1986), who wrote that personal beliefs represent the best indicator of why a given person behaves, acts and makes decisions in a certain way. Researchers unanimously agreed that each science teacher has personal beliefs about teaching and learning science which influence all of his/her respective teaching strategies and behaviours (Hewson \& Kerby, 1993), even though such beliefs about teaching are often tacit and tenacious (Shulman, 1988). The character of these beliefs and the fields where such beliefs come into play are very broad and multi-dimensional. For example, Koballa, Gräber, Coleman, and Kemp (2000) concluded that beliefs influence all interactions between teachers and pupils. They also found that teachers` beliefs about teaching and learning always include aspects of beliefs exclusive to their chosen discipline.

Evidently, beliefs influence peoples' actions by interacting of knowledge and information Deleted: with processing (Pajares, 1992). This is why teachers' beliefs about teaching and learning are crucial for establishing proper actions in classroom situations. These beliefs start to influence teachers' behaviour extremely early in teacher education programs and learners' pre-existing knowledge also interacts during the uptake and processing of new information. Fischler (2000) supported this position by evaluating the influence of student teachers` beliefs on their 
practical actions in the classroom by asking trainees to document their initial teaching experiences during school internships. Thus, it is easy to see that possessing knowledge about student teachers` beliefs is a very valuable source of information for better understanding and improving teacher training and professional development (Pajares, 1992).

In line with Pajares (1992), we view 'beliefs' as an inclusive construct which covers any mental predisposition a teacher or student teacher holds and which affects her/his behaviour in the classroom (authors, 2006; authors, 2008; authors, 2008). These beliefs can stem from personal experience, knowledge, social background, and many other different sources.

Some research on teacher trainees` beliefs is already available (see e.g. authors, 2008). Calderhead (1996), Gunstone et al. (1988) and Johnson (1988) identified different interrelated research zones, which are invaluable for defining and better understanding of teachers` beliefs. With respect to these studies, the section below presents research in the field of (i) beliefs about science teaching and learning, (ii) beliefs about the curriculum and its intentions, and (iii) beliefs about the Nature of Science.

\section{Beliefs about Teaching and Learning}

Tsai (2002) categorized student teachers' beliefs about teaching, learning, and science as traditional, process-oriented, or constructivist. The results of his study show that the majority of 37 Taiwanese science teachers held traditional beliefs in all three domains. Half of these student teachers held beliefs in the three areas that were very closely aligned to each other, a situation which Tsai characterized as "nested epistemologies" (see also Hewson et al., 1999a; Hewson et al., 1999b; Lemberger, Hewson, \& Park, 1999; Meyer et al., 1999; Tabachnick \& Zeichner, 1999). In 2006, Tsai evaluated the relationship between such nested beliefs and the student teachers' classroom actions. He concluded that "adequate coherence" existed between the student teachers` scientific epistemological beliefs and their classroom teaching (Tsai, 2006). Aguirre, Haggerty, and Linder (1990) showed that science teachers often conceptualize 
teaching as "knowledge transfer" or "an influence or change in understanding". They view learning as "an intake of knowledge," "an attempt to make sense in terms of existing understanding" or "an affective response". In the German context, Fischler (1999; 2000) evaluated physics student teachers' beliefs concerning their own physics classes at school. The predominant responses portrayed a very dominant teacher, very passive pupils, and bad memories of physics classes. Koballa et al. (2000) also described chemistry student teachers' beliefs in Germany as reproductive rather than constructive. Comparing chemistry teacher trainees and other chemistry students aiming at scientific careers, they found very similar beliefs about teaching and learning chemistry in both groups, which were couched in terms of a receptive understanding of learning. Nevertheless, such beliefs often are not fully developed or even clearly self-reflected. Boz and Uzuntiryaki (2006) showed that Turkish chemistry student teachers` beliefs are inconsistent and complex. Neuhaus and Vogt (2005) also demonstrated less-elaborated biology student teachers` beliefs about teaching and learning. Their study evaluated German biology student teachers and teachers` beliefs and distinguished three types of teachers: pedagogical-innovative, scientific-innovative, and scientific-conventional teachers. Neuhaus and Vogt claimed that beliefs in the biology domain are a mosaic of different categories and cover a wide range without showing any clear

tendency towards more conventional or more modern beliefs. However this might also be an Deleted: But Deleted: , effect of the overall number of test subjects or of other related variables. Finson, Riggs, and Jesunathadas (1999) showed that the beliefs of trainees for primary school science depend strongly on the level of personal self- efficacies (the higher the independence, the more student-centred the beliefs). Based on German student teachers`drawings, authors (2008) made an attempt to compare student teachers` beliefs about teaching and learning stemming from different science teaching domains. Using a qualitative approach based on Grounded Theory, they discovered that freshman student teachers of chemistry (and even more pronouncedly of physics) hold very traditional beliefs characterized by teacher-centred 
classroom organization, a primary orientation on the acquisition of science knowledge, and a transmission-based understanding of instruction. In contrast to this, biology and primary school teacher trainees express beliefs much more in line with current pleas for contemporary science education which is oriented towards constructivism, student activity, and scientific

literacy. A quantitative rejnterpretation of the same data arrived at the same results (Authors, 2010).

\section{Beliefs about the Curriculum and its Intentions}

Concerning beliefs about the actual objectives of science teaching, Cronin-Jones (1991) showed that the most important student outcome (according to teachers) is thought to be factual knowledge. Consequently, teachers believe that students require learning through repeated drills and practice and therefore need a great deal of supervision. While evaluating teachers`curricular beliefs in the Netherlands, Van Driel, Bulte, and Verloop (2005; 2006) found that Dutch chemistry teachers most often believed that the main goal of teaching was to introduce students to the fundamental concepts and skills within chemistry so as to prepare them for future training in chemistry. Furiò, Vliches, Guisasola, and Romo (2002) also showed that most Spanish teachers gave more weight to goals focusing on the structure and methods of science. Much less support was given to scientific literacy in a more multidimensional sense as has been pleaded for by Bybee (1997). Martin-Diaz`s (2006) study supported these findings, but added that teachers who teach Philosophy as a second subject are more likely to be concerned with the inclusion of such aspects as the Nature of Science (NOS) itself and the interrelationship Science-Technology-Society.

\section{Beliefs about the Nature of Science}

Murcia and Schibeci (1999) analysed primary science student teachers` beliefs. They found that the identified concepts contained several elements which clearly did not correspond with 
a developed understanding of NOS. The respondents displayed a naïve, unclear understanding of the scientific method and a poorly-developed understanding of scientific theory. Aguirre et al. (1990) also showed that most pre-service teachers have only a naïve idea of the Nature of Science. In this study, teachers believed that the function of science is to "discover the laws of nature". Walter-Adams (2006) showed that teachers` beliefs about NOS are a determining factor in their choices for classroom strategies.

The above studies stem from different countries and thus from different educational systems.

Furthermore, these studies focus mainly on one single aspect of (student) teachers ' beliefs. In most cases only one instrument was used for a data collection and only one science teaching domain was researched.

The present paper expands upon the authors`case studies $(2008 ; 2010)$ and integrates them with more data on the same groups of freshman science student teachers. The further aim of this paper is to discuss a methodological approach for integrating the different qualitative and quantitative data in a Mixed Methods design. We will also reflect upon how such an integrative approach can lead to a multi-facetted characterisation and comparison of the student teachers` beliefs for different science teaching domains. Furthermore for the German context the comparison between different science teaching domains is important, since there

is no teacher education program for science teachers at German universities, German teacher Deleted: training is oriented on the tertiary level education of chemistry, physics, biology and primary school science teacher.

\section{Research Questions}

This study evaluates the beliefs of different groups of freshman students stemming from the same educational and regional background in Germany. The groups attend separate teacher training programs focusing on four different domains of science teaching: secondary level 
physics, chemistry and biology (grades 5-13) and primary school science (grades 1-4). The goal of the study is to provide a concise picture of the freshmen's beliefs about science teaching and learning by integrating data from various data sources and including studies which are both qualitative and quantitative in nature. Additionally, we want to analyse the similarities and/or differences between the groups from the different teacher training programs. The research questions are as follows:

(1) Which kind of beliefs about science teaching and learning do freshman student teachers from different science domains have at the beginning of their university teacher education programs?

(2) Which general parallels and/or differences in freshman student teachers`beliefs about teaching and learning in the four different science domains can be derived by evaluating data from different qualitative and quantitative sources using an integrated Mixed Methods approach?

(3) How feasible is the integrative Mixed Methods design applied here for yielding a more multi-facetted characterization and comparison of student teachers` beliefs about science teaching and learning within the different teaching domains?

\section{Sample}

This study examines a sample consisting of freshman science student teachers from four different German universities. The sample is composed of 44 chemistry, 36 physics and 48 biology student teachers at the secondary school level (grades 5-13) and 52 primary school science candidates (grades 1-4). Data collection took place within the first two weeks of the various university teacher education programs. This was the start of higher education for almost all the subjects; therefore, the vast majority had not had any university courses 
previous to this study. This data collection period was specifically chosen because it precludes any influence on beginning students from either university coursework or professors.

As presented in Table 1, a majority of the participants possess a High School diploma (German: Abitur) from a German secondary school. The successful completion of grammar or comprehensive school is the most common qualification for university admission. Most of the student teachers graduated from secondary schools in Lower Saxony $(59,8 \%)$ or the State of Bremen (24,1\%). Both States (German: Bundesländer) are located in the Northwest of Germany. All student teachers do have comparable formal educational qualifications and most have the same regional background.

[Insert table 1 about here]

Further analysis of the participants' personal data reveals that each of the four groups is dominated by a particular gender. Female student teachers are more prevalent in biology and primary school science, whereas chemistry and physics seem to be more popular among male Deleted: s student teachers. However, even if the final data distributions in this study were influenced by gender within the sub-groups, it is important to recognize that such gender distribution is typical for these study programmes in all of Germany.

The selection of this data sample was not representative in a statistical sense. Nevertheless, most of the German student teachers have similar formal qualifications for university access. The course history and experiences for all students are driven by similar governmental syllabi and teaching traditions in the different German countries ('Länder'). All students in German schools have to take compulsory courses in primary science and in the three science teaching Deleted: P Deleted: S domains in secondary education based on these syllabi, and there is only a small chance for opting out of courses in the different science domains in the last years of upper secondary education. Also, the distribution of age and gender was very prototypical for similar groups of 
student teachers in the respective subjects. Using this point of view as a springboard, there is no sound reason for assuming that these student teachers are special in any respect. We should not assume that the results would differ notably by sampling a new test group from other German universities involved in science teacher education.

\section{Methods}

There is a distinction between qualitative and quantitative research methods (e.g. Devetak, Glazar, \& Vogrinc, 2010) in educational and science educational research. In the past, these two different approaches were thought to oppose each other, although the incommensurateness of this position has weakened in recent years (Mayring, 2001). Mayring (2001) gave three reasons for overcoming the opposing sides of quantitative and qualitative research: (i) a combination of both methods might possibly avoid the disadvantages inherent in both individual approaches, (ii) using both qualitative and quantitative approaches may overcome the phenomenon of researchers` often lop-sided thinking, and (iii) the existence of a final and clear limit between qualitative and quantitative research approach is difficult to prove (see also Newman \& Benz, 1998). This overcoming of opposites has been termed "Mixed Methods", a relatively new research tradition. Tashakkori and Teddlie (2003) refer to it in "its adolescence" (p. 3). Currently, Mixed Methods studies are still underrepresented in science education research, although a growing percentage of studies based on Mixed Methods has been published in science education in recent years (Devetak et al., 2010) Our study used different instruments - both qualitative and quantitative - to generate a database characterizing German freshman science teachers' beliefs about teaching and learning. The different dimensions evaluated by these various tools are separate, independent areas of beliefs. As a consequence, the beliefs were first analysed individually (see also Törner, 1996). 
To better analyse and understand the field of study we opted for an integrated Mixed Methods Design. An integrative model of Mixed Methods Research always tries to data integration during the whole process of data collection, but also during data analysis and data interpretation as well. This is a more consequent approach than sequential models in which qualitative data is either generalized by a quantitative study, or where specific findings in a quantitative study are researched in more detail, e.g. by interviews. For this paper, an integration of different qualitative and quantitative data sets as described by Mayring and Alexandrowicz (2004) was accomplished. In our approach we tried to avoid giving theoretical priority to either the qualitative or the quantitative data. We attempted to perform an integrated Mixed_Methods_Design. The theoretical perspective is implicit which means that the guiding theoretical framework is not described explicitly prior to the different studies and the mode of their integration (Table 2). The theory of considering the findings along a spectrum of modern to traditional beliefs was itself a part of the results of data evaluation and integration. The spectrum was constructed using an evaluation of the qualitative data by Grounded Theory and further defined in the interplay within the explicit frameworks of the different quantitative studies.

\section{[Insert table 2 about here]}

\section{Qualitative Study}

In the qualitative part of the study, the participants were instructed to draw themselves as science teachers in a typical classroom situation and asked to answer four open questions. This idea was adopted from the 'Draw-A-Science-Teacher-Test Checklist' (DASTT-C) by Thomas, Pedersen, and Finson (2001) and supplemented with questions about teaching objectives and prior activities (authors, 2008). An example of the data is to be found in Appendix 1. The data analysis pattern was developed by the beginning of the Grounded 
Theory (GT), building categories based on data as described in authors (2008). The core category developed by GT is a range between the predominance of more traditional and more modern teaching orientation. More modern in this case means in line with current educational theory. Three five-step scales were developed using GT and focussed on: 1) Beliefs about Classroom Organisation, 2) Beliefs about Teaching Objectives and 3) Epistemological Beliefs. All five-step scales were labelled from -2 (for more traditional) towards +2 (for more modern beliefs) (Table 3).

\section{[Insert table 3 about here]}

Data validity was achieved through independent rating and searching for inter-subjective agreement (Swanborn, 1996). Results of the qualitative study alone were described in authors (2008). Starting with the idea of five-step scales developed and used in the qualitative study, a decision was made to develop similar scales for the quantitative data sets as well. This also provided a basis for the later integration of the data.

\section{First quantitative study}

The first quantitative study was a rejnterpretation of a data subset previously analysed in the qualitative study described above. Based on quantitative analysis, a five-step scale was developed for the student teachers' drawings and their answers on the first two questions from the original DASTT-C application (as given in the original study by Thomas et al. (2001)). Data analysis was performed using the checklist presented in the same paper. In the current study, the data where analysed for the presence of each of 13 single characteristics representing components of a student- or teacher-centred view, e.g. using the blackboard, or the teacher standing in front of the class represent a more teacher-centred view. The more often these elements occurred in the data, the stronger the characterization of the teacher

Deleted: -

Deleted: $\mathrm{z}$ 
trainee as possessing teacher-centred beliefs became. Thomas et al. (2001) used a score of 7 or more points as typical for someone with teacher-centred beliefs and a score below 4 to represent student-centred views (see also authors, 2010). In our approach, the frequency for each score (0 to 13$)$ in each group was calculated. Furthermore, the relative frequency for the scores was calculated as well. Based on the idea of grouping on the basis of empirical quantiles (Koenker \& Bassett, 1978), a five-step scale was developed. Each step on the scale represents $20 \%$ of the relative frequency for the scores, and corresponds to a group of scores from the checklist. Interpreting the data revealed by this scale gives us insights into Beliefs about Teaching Style. The results are represented in a spectrum ranging from teacher-centred to student-centred beliefs (Table 4).

[Insert table 4 about here]

\section{Second quantitative study}

The next quantitative sub-studies stem from one Likert-questionnaire. The questionnaire focused on student teachers' beliefs about the emphases of curricula (Van Driel et al., 2006). The original questionnaire contains 13 items. For our study, part of the data was used covering two specific Curriculum Emphases: "Fundamental Science (FS)" and "Science, Technology and Society (STS)" (together 8 items). In the current debate surrounding Germany's new National Science Standards and modern science education (Klieme \& Steinert, 2004), Fundamental Science (FS) is viewed as representing more traditional beliefs, whereas Science, Technology and Society (STS) is characterized as being more modern (see also Van Driel et al., 2005). For indices for internal consistency of the questionnaire are satisfactory $(\alpha=.6)$. The mean scores were then subtracted: STS-mean score minus FS-mean score. A five-step scale for the relative frequency in the differences between the mean scores was also calculated by grouping the sample based on empirical quantiles (Koenker \& Bassett, 
1978). 20\%-quantiles were chosen in order to achieve a five-step scale, which is based on describing how scientific knowledge and science learning interact with technology and society. The scale for Beliefs about the Value of Learned Scientific Knowledge looks at the reasons behind learning science: just to possess scientific knowledge or to use such knowledge to (inter)act within society (Table 4).

\section{Third quantitative study}

The second Likert-questionnaire evaluated student teachers' beliefs about the nature of school science (Chen, Taylor, \& Aldridge, 1997). This dimension is represented by the mean scores from the two scales dealing with the Beliefs about the Nature of School Science. Together this part contains a total 20 items. For indices for internal consistency for the questionnaire are very satisfactory $(\alpha=.8)$. The relative frequencies for the mean scores for the whole sample were calculated. A five-step scale was developed by grouping the sample based on empirical quantiles about the frequencies for the mean scores. The new scale for Beliefs about the Nature of School Science Knowledge shows a range grading student teachers' level of understanding of knowledge and inquiry within school science. This range represents the spectrum between two possible extremes: scientific knowledge as memorized, unchangeable facts on the one hand, and knowledge as tentative and something created within a sociohistoric context on the other (Table 4). All three quantitative 5-step scales were given the same range of labels from -2 (for more traditional) towards +2 (for more modern beliefs).

\section{Integration of the qualitative study and the three quantitative studies}

The qualitative scales developed using beginning steps of Grounded Theory (Glaser and Strauss, 1967) do not represent a linear scale. But in this context, we must also remain aware that Likert-scales often are not read as being linear in all cases, but are nevertheless 
commonly handled using statistical methods. Keeping this in mind, several statistical steps were necessary in order to integrate the qualitative and quantitative data sets.

A grouping based on empirical quantiles was again applied to finally integrate all the data and to allocate the sub-groups within the whole population. This was possible because high (i.e. more modern) and the low (i.e. more traditional) scores were both represented in all of the four sub-groups of student teachers and in all the four different studies. Starting from this pint, the raw scores are corresponded to the spectrum presented in the Tables 3 and 4 . The mean scores for each of the six five-step scales were calculated. Relative frequencies for the twenty-four mean scores were calculated and a grouping based on empirical quantiles of the whole population was used.

\section{Results}

Table 5 presents the allocation of the subgroups within each scale. It also indicates whether beliefs which are more traditional or more modern predominate in each of the sub-groups. For better visual representation of the data, each number value was given a shade of gray: the lighter the colour, the more in line the beliefs are with modern educational theory. The first three categories stem from the qualitative data and last three from the quantitative. The column representing the freshman physics student teachers group is the darkest in comparison to the others. The neighbouring chemistry column is only a shade lighter. This reflects the fact that the two groups predominantly achieved scores between -2 and -1 , respectively. The further we go to the right in Table 5, the lighter become the colours.

[Insert table 5 about here]

Looking at the details we can see several general tendencies: 
- Freshman physics student teachers hold very traditional beliefs. Their scales for Beliefs about the Value of Learned Scientific Knowledge and Beliefs about the Nature of School Scientific Knowledge averaged a score of 0. In all other scales, the physics trainees are the most traditional of all the participants.

- Freshman chemistry student teachers also lean heavily towards more traditional beliefs. They achieved scores of -1 in all of the categories except Beliefs about the Value of Learned Scientific Knowledge.

- Freshman biology student teachers achieved an average score of +1 (in Classroom Organisation they scored a +2 ). In the categories Beliefs about the Value of Learned Scientific Knowledge and Beliefs about the Nature of School Scientific Knowledge they evidenced a score of 0 .

- Freshman primary science student teachers have the most modern beliefs of all the groups. They averaged a score of +2 in four out of the six categories.

\section{Discussion}

The results for Research Questions 1 and 2 (see above) show that integration of the qualitative and quantitative data allowed us to provide a quite holistic comparison of student teachers` beliefs from different science teaching domains about different aspects of teaching and learning. Physics student teachers hold the most traditional beliefs in most of the qualitative and quantitative categories. Chemistry trainees also express traditional beliefs when starting their teacher training program, although not quite as strongly as their physics counterparts. At the other end of the spectrum, biology candidates hold more modern beliefs about teaching and learning in their domain. This trend became even more obvious when analysing the group of future primary school science teachers. Interpretation of the data focused on many different aspects of the subjects` beliefs and was based on completely different kinds of data and evaluation methods. The results of the study presented here 
support the findings of Koballa et al. (2000) which show that (student) teachers ' beliefs about teaching and learning include aspects of beliefs exclusive to their chosen discipline. Contrary to the study of Neuhaus and Vogt (2005), the current study found clear tendencies in student teachers` beliefs towards more traditional or more modern beliefs. Furthermore, all these findings support the interpretation of part of the data presented in authors $(2008 ; 2010)$ but on an even broader and more integrative base. But, due to the process of data integration they are also of a different kind. First, authors (2008) described the development of a particular evaluation pattern in which the different student teachers were allocated. This first study was later expanded for a much larger group of test subjects (published as authors (2008)). Authors (2010) described the quantitative study using the tool developed by Thomas et al. (2001) to give the scale for rating the individuals. This latest study uses the Mixed Method to yield a comparison of the different group averages and their allocation along the scales when placed alongside one another. Finally, comparing our results to Tsai`s (2002) study revealed that, once again, student teachers` beliefs from different areas are closely aligned with each other. We can therefore talk about "nested" beliefs. This means that teacher educators must be cognizant of the connection between learners` beliefs within their networks when starting to influence teacher trainees` beliefs systems in one direction or the other.

Concerning Research Question 3 (see above) there are three qualitative-quantitative pairs of categories that show some relationship with one another. Such relationships provide us with more support for our findings when applied in the sense of triangulation. Each qualitative category can be linked with a related quantitative category, even though interpretation of our tested construct simply shows an overlap, but not total congruence. Therefore, the question emerges how much do the qualitative and quantitative categories overlap, complement, or interact with each other. This may be answered through theoretical reflection. Table 6 presents the six categories with short descriptions and groups those most obviously related to one another. 
[Insert table 6 about here]

In

In the comparison of Beliefs about Classroom Organisation and Beliefs about Teaching Style, the second category focuses only on student- or teacher-centeredness, while Beliefs about Classroom Organisation contains more aspects. A qualitative category tells us much about student teachers' understanding of the organisation of learning processes within the classroom. Both concepts do overlap in their orientation towards student-teacher interactions and activities during instructional time. Data from both sources triangulate to a high level, even though the concepts do not express exactly the same ideas.

Both categories dealing with the objectives of the teaching and learning of science (Beliefs about Teaching Objectives and Beliefs about the Value of Learning Scientific Knowledge) do not associate quite as strongly. However, Beliefs about Teaching Objectives analyses teacher trainees' orientation towards reaching the objectives of scientific literacy. This idea is related to the category Beliefs about the Value of Learning Scientific Knowledge, which asks the participant about which kind of knowledge school science should develop. Even here, the questions probe which specific type of scientific knowledge gained in school allows students to function as well-informed, educated citizens. This means that both the type of knowledge to be taught and the overall objectives to be reached are related to each other through the intentions of science teaching in these two categories.

Epistemological Beliefs and Beliefs about the Nature of School Scientific Knowledge are more widely separated then the other category pairings. The quantitative category focuses more extensively on knowledge characteristics and asks about the nature of the knowledge which should be taught in schools. In this context, some researchers (e.g. Tsai (2006), Tsai and Liu (2005) or Ryan and Aikenhead (1992)) add the concept of scientific epistemological beliefs to the argument. They see a connection between the Nature of Science and
Deleted:

Deleted: $\mathrm{z}$ 
epistemological beliefs, “...which addresses the issues regarding the philosophical assumptions, values, developments, and conceptual inventions in science, consensus making in scientific communities, and features of scientific knowledge” (Tsai, 2006, p. 223). More simply put, scientific epistemological beliefs indicate one's personal views about the actual nature of scientific knowledge (see Im \& Pak, 2004). The category Epistemological Beliefs inquires into the process of learning and the creation of knowledge in one's mind. But there are nonetheless parallels between the two categories, for example the constructivist viewpoint of the tacit nature of knowledge, which comes with an advanced understanding of science. In both cases, knowledge is embedded in many variables from its environment and the way the knowledge was generated. Similar parallels can be seen on the other end of the spectrum, where a view of knowledge as "facts" is linked to a transmission-oriented understanding of teaching and learning.

Thus, qualitative and quantitative categories overlap each other, but not as fully as one might hope or expect. The categories can be seen as supplementing or complementing one another. Through the combination of the different scales we can reveal more information than with only one of the perspectives singly. In addition, interpreting the data sets together led us to a deeper understanding of and more intense reflection upon each of the individual categories itself. All three qualitative categories express much more then the quantitative categories do, but by their qualitative nature and generation by Grounded Theory are not as sharp focussing one specific aspect as are the quantitative categories, Furthermore, we should be conscious

that "only" similar beliefs were measured by the qualitative and quantitative data. The qualitative categories simply cast a broader net than their quantitative counterparts.

This integration can be viewed as triangulation, but not in the classical sense. There are limits which we need to keep in mind when judging the overlaps of present studies and their potential for triangulation. The biggest criticism of triangulation is that mutual validation of the results is limited, because qualitative and quantitative methods relate to different 
paradigms. Fielding and Fielding (1986) stated that using qualitative and quantitative methods jointly can reveal the depth and breadth of the results, but not increase the validity of the studies. The qualitative results are much more detailed and dig deeper into student teachers` beliefs. However, qualitative results are usually more susceptible to mistakes made in the researchers' interpretations. Compared to this, quantitative results are easily reconstructed and more comprehensible. It is quite easy for independent researchers to recalculate and reexamine a colleague's results. Quantitative results are, however, indistinct, because the questionnaires are developed beforehand and are also influenced by the researchers` own beliefs and opinions.

Based on this, we can conclude that both qualitative and quantitative studies have the ability to support one another in their general interpretations. Furthermore, we can state that the integrated approach of qualitative and quantitative data can potentially lead to a more settled and general consideration of student teachers' beliefs.

\section{Conclusions and Implications}

The evaluation of student teachers' beliefs is very important for better understanding of their learning during teacher training (Boz \& Uzuntiryaki, 2006; Fischler, 1999). Therefore, an evaluation of such beliefs should necessarily be part of their university education. This would make both science teachers and their educators explicitly aware of such beliefs and their often substantial consequences. Reflection upon and discussion of explicit personal beliefs can also be helpful in fostering conceptual changes in teacher trainees and in steering them away from more traditional mindsets towards more modern beliefs. I.e., the described application of the modified version of the DASTT instrument might offer a fruitful tool to make explicit hidden and unconscious beliefs about teaching and learning at different stages of teacher training (Authors, 2008) to lead to conceptual change. The data described in respective studies can offer help to orient oneself in a spectrum of other student teachers and show that beliefs can 
be changed over time. Student teachers could also start reflecting on concrete teaching experiences in order to articulate and share their (tacit) general pedagogical and epistemological ideas. Discussions with others may help trainees to express their beliefs of who they are and exactly how they intend to act as a teacher in their respective discipline.

Such self-reflection may help them to further refine their professional identity.

Deleted: $\mathrm{n}$

Science education should also concern itself with the question of whether or not student teachers' beliefs function as a springboard for career choice when choosing a school subject to teach. It is a plausible hypothesis that - if all potential science teachers possess beliefs similar to those found in this study - it should come as no surprise that the numbers of chemistry and physics student teacher applicants are so low when compared to biology or primary science. If this argument is right, the miss in attracting young people to become teachers in chemistry and physics which we see in many countries will only change if the practice of teaching will change. To make their beliefs explicit to the student teachers might help, if the new generation of chemistry and physics teachers was able to shift their beliefs towards more modern ones. More importantly, we must ask ourselves: 1) Why, if such stereotypical beliefs and opinions are so dominant among physics and chemistry student teachers, do potential teachers choose their subject in the first place? and 2) What type and quality of student teachers do universities and schools get for these two particular subjects? Furthermore, we need to focus more on the development of science teacher trainees` beliefs during their university teacher education programs and on the influence exerted by university courses and seminars. We cannot answer this last question with this study, but the current data should motivate us to look more deeply into these pivotal questions. But perhaps science teacher training courses should first embark on a plan to better make prevalent beliefs explicit to teacher trainers and student teachers themselves, so that they self-reflect on them for further learning. The tools and data presented here may help individuals to reflect upon their own beliefs and to appraise them in comparison to others. 
Finally, this attempt to integrate both qualitative and quantitative data within an integrative Mixed Methods design proved itself valuable for 1) re-thinking the assumptions made in other fields of research, 2) leading to a more concise picture about the varying beliefs of student teachers about teaching and learning in science, and finally 3) giving more support for the evidence previously documented in authors $(2008 ; 2010)$. Such Mixed Methods Design might help to draw more holistic pictures of student teachers' beliefs, maybe under inclusion of even more tools. In the end such designs should be used to monitor the development and to better reflect the interaction of the different dimensions of the science student teachers beliefs. Thus, this design can be considered as a good starting point for further research.

\section{References}

Aguirre, J. M., Haggerty, S. M., \& Linder, C. J. (1990). Student-teachers` conceptions of science, teaching and learning: a case study in preservice teacher education. International Journal of Science Education, 12, 381-390.

Bandura, A. (1986). Social foundation of thought and action: A social cognitive theory. Englewood: Prentice-Hall.

Boz, Y. \& Uzuntiryaki, E. (2006). Turkish prospective chemistry teachers` beliefs about chemistry teaching. International Journal of Science Education, 28, 1647-1667

Bybee, R. W. (1997). Toward an understanding of scientific literacy. In W. Gräber \& C. Bolte (Eds.) Scientific literacy - an international symposium (pp. 37-68). Kiel: IPN.

Calderhead, J. (1996). Teachers: beliefs and knowledge. In: Berliner, D. C., \& Calfee, R. C. (eds.): Handbook of Educational Psychology. (p. 709-725). New York: Macmillan.

Chen, C.-C., Taylor, P. C., \& Aldridge, J. M. (1997). Development of a questionnaire for assessing teachers` beliefs about science and science teaching in Taiwan and Australia. Paper presented at the annual NARST conference. Chicago. 
Clark, C. M., \& Peterson, P. L. (1986). Teachers`thought processes. In M. C.Wittrock (Ed.) Handbook of Research on Teaching (p. 255-296). New York: Macmillan.

Creswell, J. W (2003). Research Design: Qualitative, Quantitative, and Mixed Method Approaches ( $2^{\text {nd }}$ ed.). Thousand Oaks: Saga Publications.

Cronin-Jones, L. (1991). Science teachers` beliefs and their influence on curriculum implementation: two case studies. Journal of Research in Science Teaching, 28, 235-250.

Czerniak, C. M., \& Lumpe, A. T. (1996). Relationship between teacher beliefs and science education reform. Journal of Science Teacher Education, 7, 247-266.

Devetak, I., Glazar, S.A., \& Vogrinc, J. (2010). The role of qualitative research in science education. Eurasia Journal of Mathematics, Science \& Technology Education, 6(1), 7784.

Fielding, N. G., \& Fielding, J. L. (1986). Linking Data. Qualitative Research Methods (Vol. 4). Beverly Hills: Sage.

Finson, K. D., Riggs, I. M., \& Jesunatahadas, J. (1999). The relationship of science teaching self efficacy and outcome expectancy to the Draw-A-Science-Teacher-Teaching Checklist. Paper presented at the annual international conference of the Association of Educators of Teachers of Science, Austin, TX.

Fischler, H. (1999). The impact of teaching experiences on student-teachers ‘ and beginning teachers' conceptions of teaching and learning science. In J. Loughran (Ed.) Researching teaching (p. 172-197). London: Falmer Press.

Fischler, H. (2000). Über den Einfluß von Unterrichtserfahrungen auf die Vorstellungen vom Lehren und Lernen bei Lehrerstudenten der Physik (Teil 2: Ergebnisse der Untersuchung). Zeitschrift für Didaktik der Naturwissenschaften, 6, 79-95.

Furiò, C., Vliches, A., Guisasola, J., \& Romo, V. (2002). Spanish teachers`view of the goals of science education in secondary education. Research in Science \& Technological Education, 20, 39-52. 
Glaser, B. G., \& Strauss, A. L. (1967). The discovery of Grounded Theory: strategies for qualitative research. Chicago: Aldine.

Gunstone, R. F., Baird, J. R., Fensham, P. J., \& White, R. T. (1988). Understanding teacher education. Paper presented at the International Council of Associations of Science Education World Conference, Canberra, Australia.

Hewson, P. W., \& Kerby, H. W (1993). Conceptions in teaching science held by experienced high school science teachers. Paper presented at the Annual Meeting of the National Association for Research in Science Teaching. Washington, USA.

Hewson, P. W., Tabachnik, B. R., Zeichner, K. M., \& Lemberger, J. (1999a). Educating prospective teachers of biology: findings, limitations and recommendations. Science Education, 88, 373-384.

Hewson, P. W., Tabachnick, B. R., Zeichner, K. M., Blomker, K. B., Meyer, H., Lemberger, J., Marion, R., Park, H.-J., \& Toolin, R. (1999b). Educating prospective teachers of biology: introduction and research methods. Science Education, 88, 247-273.

Im, S., \& Pak, S.-J. (2004). Secondary and university students' expectations on learning physics. Journal of the Korean Physical Society, 44(2), 217-222.

Johnson, K. (1988). Changing teachers`conceptions of teaching and learning. In: Calderhead, J. (ed.): Teachers Professional Learning. (p.169-195). Lewes: Falmer Press.

Klieme, E., \& Steinert, B. (2004). Einführung der KMK-Bildungsstandards. Der Mathematische und Naturwissenschaftiche Unterricht, 57, 132.

Koenker, R., \& Bassett, G. (1978). Regression quantiles. Econometric, 46 (1), 33-50.

Koballa, T., Gräber, W., Coleman, D. C., \& Kemp, A. C. (2000). Prospective gymnasium teachers' conceptions of chemistry learning and teaching. International Journal of Science Education, 22, 209-224. 
Lemberger, J., Hewson, P.W., \& Park, H.-J. (1999). Relationships between prospective secondary teachers` classroom practice and their conceptions of biology and of teaching science. Science Education, 88, 347-371.

Martin-Diaz, M. J. (2006). Educational background, teaching experience and teachers`views on the inclusion of Nature of Science in science curriculum. International Journal of Science Education, 28, 1161-1180.

Mayring, P. (2001). Kombination und Integration qualitativer und quantitativer Analyse. In: Forum Qualitativer Sozialforschung / Forum: Qualitative Social Research [On-line Journal], 2(1). http://qualitative-research.net/fqs/fqs.htm, last view: 21.03.2010

Mayring, P., \& Alexandrowicz, R. (2004). Mixed methodologies - Modelle und Beispiele. 44. Kongress de Deutschen Gesellschaft für Psychologie (p. 234), Göttingen.

Meyer, H., Tabachnick, B. P., Hewson, P.W., Lemberger, J., \& Park, H.-J. (1999). Relationships between prospective elementary teachers`classroom practice and their conception of biology and teaching science. Science Education, 88, 323-346.

Murcia, K., \& Schibeci, R. (1999). Primary student teachers` conceptions of the nature of science. International Journal of Science Education, 21, 1123-1140.

Newman, I., \& Benz, C. R. (1998). Qualitative-Quantitative Research Methodology: Exploring the Interactive Continuum. Carbondale: Southern Illinois University Press.

Neuhaus, B., \& Vogt, H. (2005). Dimensionen zur Beschreibung verschiedener Biologielehrertypen auf Grundlage ihrer Einstellungen zum Biologieunterricht. Zeitschrift für Didaktik der Naturwissenschaften, 11, 73-84.

Nespor, J. (1987). The role of beliefs in the practice of teaching. Journal of Curriculum Studies, 19, 317-328.

Pajares, M. F. (1992). Teachers` beliefs and educational research: cleaning up a messy construct. Review of Educational Research, 62, 307-332. 
Ryan, A. G., \& Aikenhead, G. S. (1992). Students' preconceptions about the epistemology of science. Science Education, 76, 559 - 580.

Shulman, L. (1988). The danger in dichotomous thinking in education. In P. Grimmet \& G. Erickson (Eds.), Reflection in teacher education (pp. 31-39). New York: Teachers College Press.

Swanborn, P. G. (1996). A common base for quality control criteria in quantitative and qualitative research. Quality \& Quantity, 30, 19-35.

Tabachnick, B. R., \& Zeichener, K. M. (1999). Idea and action: Action research and the development of conceptual change teaching of science. Science Education, 88, 309-322.

Tashakkori, A., \& Teddlie, C. (2003). Handbook of Mixed Methods in social and behavioural research. Thousand Oaks: Sage.

Thomas, J., Pedersen, J. E., \& Finson, K. (2001). Validation of the Draw-A-Science-TeacherTest Checklist (DASTT-C). Journal of Science Teacher Education, 12, 295-310.

Törner, G. (1996). Mathematische Weltbilder von Lehrern. Beiträge zum Mathematikunterricht, 433-436.

Tsai, C.-C. (2002). Nested epistemologies: science teachers` beliefs of teaching, learning and science. International Journal of Science Education, 24, 771-783.

Tsai, C.-C. (2006). Teachers`scientific epistemological views: the coherence with instruction and students`views. Science Education, 91, 222-243.

Tsai, C.-C., \& Liu, S.-Y. (2005). Developing a multi-dimensional instrument for assessing students' epistemological views toward science. International Journal of Science Education, 27, 1621-1638.

Van Driel, J. H., Bulte, A. M. W., \& Verloop, N. (2005). The conceptions of chemistry teachers about teaching and learning in the context of curriculum innovation. International Journal of Science Education, 27, 303 -322. 
Van Driel, J. H., Bulte, A. M. W., \& Verloop, N. (2006). Using the curriculum emphasis concept to investigate teachers`curricular beliefs in the context of educational reform. Journal of Curriculum Studies, 40, 107-122.

Valanides, N., \& Angeli, C. (2002). Challenges in achieving scientific and technological literacy: Research directions for the future. Science Education International, 13, 2-7.

Walter-Adams, S. (2006). The relationship between understanding of the nature of science and practice: the influence of teachers` beliefs about education, teaching and learning. International Journal of Science Education, 28, 919-944.

Authors (2006). Paper in a book of proceedings.

Authors (2008). Book.

Authors (2008). Paper in a refereed journal.

Authors (2008). Paper in a refereed journal.

Authors (2010). Paper in a refereed journal. 
1

2

3

4

5

6

7

8

9

10

11

12

13

14

\section{Appendix 1: Examples of the data source}

\section{$\underline{\text { Student teachers`drawings }}$}

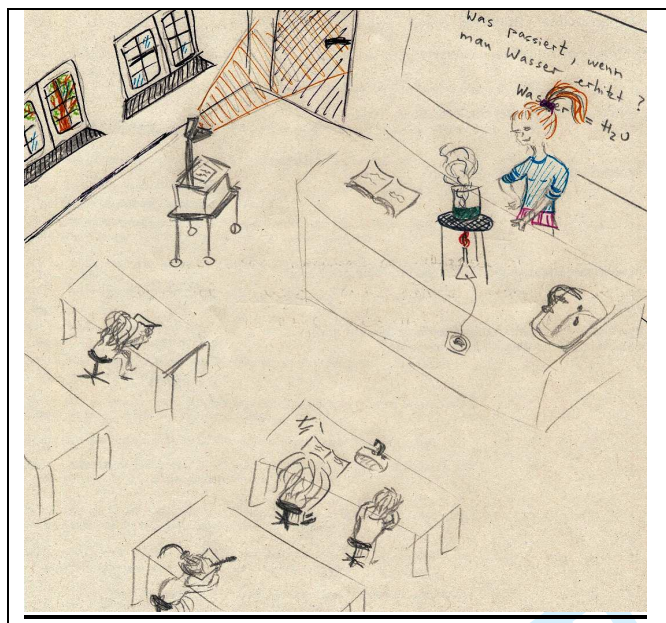

Teacher:

I try to teach the kids something by making it experimentally understandable, since it is easier to explain and understand things this way. Naturally, one shouldn `t just perform teacher experiment, but also let the kids experiment, since this awake their interest in Chemistry.

\section{Students:}

- They listen attentively (during experimenting), because there is something to observe and to marvel about.

Aims:

Teaching the students not just theoretical things, but also practical ones.

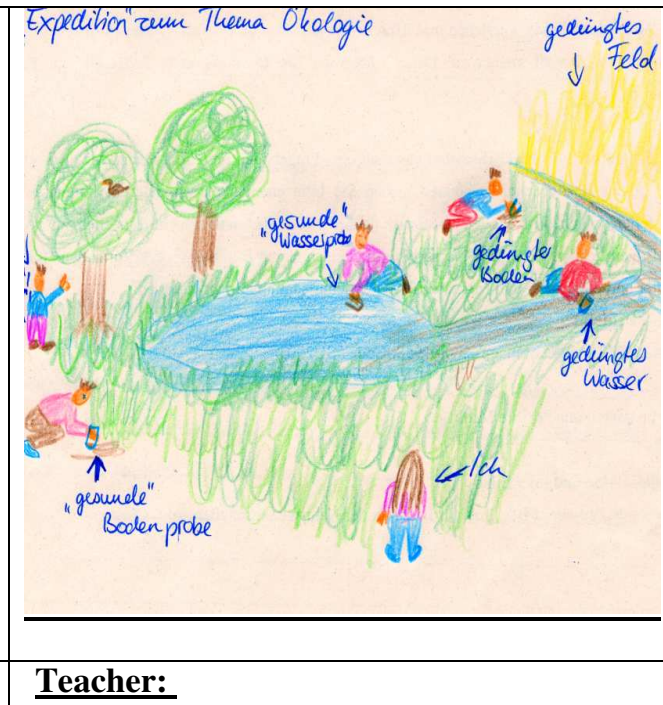

I took the students to an ecologically interesting place. Before, we talked about what we are going to do there. Students can ask me questions but most of the time, I supervise them.

\section{Students:}

Students should collect samples and analyse them. They should learn about the environment and look if there is any intact ecosystem. At the end, they should prepare a presentation.

Aims:

Awareness about the environment, dilatation of the knowledge, skills in analysing samples, writing a journal, reasoning.

\section{$\underline{\text { Likert-items about student teachers`curricular beliefs }}$}

- I consider knowledge of chemical equilibrium important because it aids students understanding of a large number of different chemical phenomena. 
- I think it is important to pay attention in my lessons to social issues of current interest in which chemistry plays role.

\section{$\underline{\text { Likert-items about student teachers` beliefs about the nature of school science }}$}

- In science classes, student should explore different methods of investigation.

- In school science, students should be critical of accepted theories. 
1

2

3

4

5

6

7

8

9

10

11

12

13

\section{Captions}

Table1. Selected characteristics of the participants in the study

Table 2. Integration of the qualitative and quantitative data in the present study (grey) in comparison to potential alternatives (compare Creswell, 2003)

Table 3. An overview of the scales from the qualitative part

Table 4. An overview of the scale from the quantitative studies

Table 5. Presentation of the data according to Mixed Methods (The lighter the colour, the more modern the beliefs in a range from -2 to +2 )

Table 6. Confrontation of qualitative and quantitative categories 
Table1. Selected characteristics of the participants in the study

\begin{tabular}{|c|c|c|c|}
\hline Characteristic & Options & Number & Percentage \\
\hline \multirow[t]{4}{*}{ Age } & under 21 & 99 & 55,0 \\
\hline & $21-25$ & 60 & 33,4 \\
\hline & $25-30$ & 13 & 7,2 \\
\hline & over 30 & 8 & 4,4 \\
\hline Federal State where secondary & Bremen & 42 & 23,3 \\
\hline \multirow[t]{4}{*}{ education completed } & Lower Saxony & 104 & 57,8 \\
\hline & North Rhineland - Westphalia & 12 & 6,7 \\
\hline & Schleswig - Holstein & 4 & 2,2 \\
\hline & Other & 18 & 10,0 \\
\hline Type of school where & Grammar school & 151 & 83,9 \\
\hline secondary education & Comprehensive school & 20 & 11,1 \\
\hline completed & Other & 9 & 5,0 \\
\hline
\end{tabular}

$N=180$ 
Table 2. Integration of the qualitative and quantitative data in the present study (grey) in comparison to potential alternatives (compare Creswell, 2003)

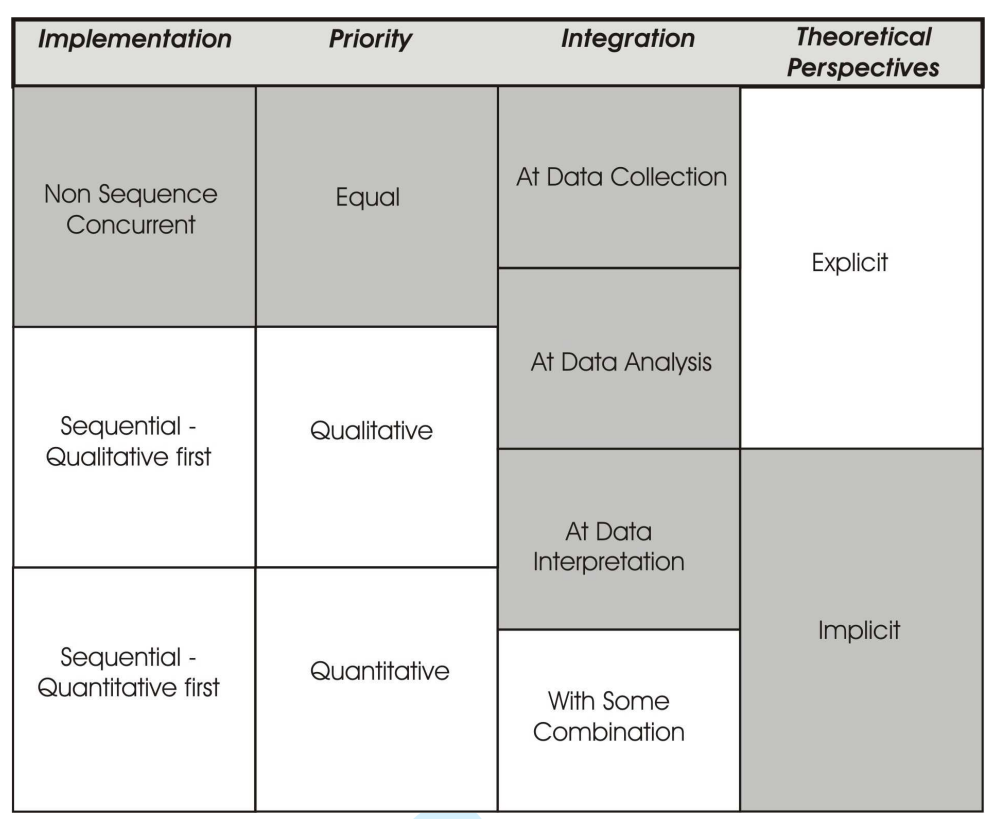


Table 3. An overview of the scales from the qualitative part

\begin{tabular}{|c|c|c|c|}
\hline & Traditional beliefs & & Modern beliefs \\
\hline $\begin{array}{l}\text { Belief about } \\
\text { Classroom } \\
\text { Organisation }\end{array}$ & $\begin{array}{l}\text { The classroom } \\
\text { activities are mostly } \\
\text { teacher-centred, } \\
\text { directed, controlled and } \\
\text { dominated by the } \\
\text { teacher. }\end{array}$ & $-2,-1,0,1,2$ & $\begin{array}{l}\text { Classes are dominated } \\
\text { by student activity and } \\
\text { students are (at least } \\
\text { partially) able to } \\
\text { choose and control } \\
\text { their activities. }\end{array}$ \\
\hline $\begin{array}{l}\text { Belief about } \\
\text { Teaching } \\
\text { Objectives }\end{array}$ & $\begin{array}{l}\text { The focus of Science } \\
\text { teaching is more or less } \\
\text { exclusively focused on } \\
\text { content learning. }\end{array}$ & $-2,-1,0,1,2$ & $\begin{array}{l}\text { Learning of } \\
\text { competencies, problem } \\
\text { solving or thinking in } \\
\text { relevant contexts are } \\
\text { the main focus of } \\
\text { teaching. }\end{array}$ \\
\hline $\begin{array}{l}\text { Epistemological } \\
\text { Beliefs }\end{array}$ & $\begin{array}{l}\text { Learning is passive, } \\
\text { over-directed and } \\
\text { controlled by } \\
\text { dissemination of } \\
\text { knowledge. }\end{array}$ & $-2,-1,0,1,2$ & $\begin{array}{l}\text { Learning is a } \\
\text { constructivist, } \\
\text { autonomous and self- } \\
\text { directed activity. }\end{array}$ \\
\hline
\end{tabular}


1

2

3

4

5

6

7

8

9

Table 4. An overview of the scale from the quantitative studies

\begin{tabular}{|c|c|c|c|}
\hline & Traditional beliefs & & Modern beliefs \\
\hline Belief about & Teacher-centred. & $\leftrightarrow$ & Student-centred. \\
\hline Teaching Style & $\begin{array}{l}\text { Teacher lectures and } \\
\text { students watch and } \\
\text { listen. }\end{array}$ & $-2,-1,0,1,2$ & $\begin{array}{l}\text { Student activities } \\
\text { dominate lessons. }\end{array}$ \\
\hline $\begin{array}{l}\text { Beliefs about the } \\
\text { Value of Learned } \\
\text { Scientific Knowledge } \\
\text { (STS minus FS) }\end{array}$ & $\begin{array}{l}\text { Knowledge is value } \\
\text {-free }\end{array}$ & $\begin{array}{c}\overleftrightarrow{\leftrightarrow} \\
-2,-1,0,1,2\end{array}$ & $\begin{array}{l}\text { Knowledge has } \\
\text { importance for the } \\
\text { learner of how to act in } \\
\text { the society. }\end{array}$ \\
\hline $\begin{array}{l}\text { Belief on the Nature } \\
\text { of School Science } \\
\text { Knowledge }\end{array}$ & $\begin{array}{l}\text { Knowledge as saved, } \\
\text { unchangeable facts } \\
\text { (objectivistic view) }\end{array}$ & $\begin{array}{c}\leftrightarrow \\
-2,-1,0,1,2\end{array}$ & $\begin{array}{l}\text { Knowledge is tentative, } \\
\text { created within a socio- } \\
\text { historic context (post- } \\
\text { positivistic view). }\end{array}$ \\
\hline
\end{tabular}


Table 5. Presentation of the data according to Mixed Methods (The lighter the colour, the more modern the beliefs in a range from -2 to +2 )

\begin{tabular}{|l|l|l|l|} 
& Physics & Chemistry $\quad$ Biology & $\begin{array}{l}\text { Primary } \\
\text { Science }\end{array}$ \\
\hline $\begin{array}{l}\text { Beliefs about the Classroom } \\
\text { Organisation }\end{array}$ & & & \\
\hline $\begin{array}{l}\text { Beliefs about Teaching } \\
\text { Objectives }\end{array}$ & & & \\
\hline Epistemological Beliefs & & & \\
\hline Beliefs about Teaching Style & & & \\
\hline $\begin{array}{l}\text { Beliefs about the Value of } \\
\text { Learning Scientific Knowledge }\end{array}$ & & & \\
\hline $\begin{array}{l}\text { Beliefs about Nature of School } \\
\text { Science Knowledge }\end{array}$ & & & \\
\hline
\end{tabular}


1

2

3

4

5

6

7

8

9

Table 6. Confrontation of qualitative and quantitative categories

\begin{tabular}{l}
\hline Qualitative Categories \\
\hline Beliefs about Classroom Organization \\
The focus is on classroom activities and \\
interaction. The spectrum ranges between \\
domination of the activity by the teacher or \\
by the students.
\end{tabular}

\section{Beliefs about Teaching Objectives}

The objectives of Science education are the focus. Answers ranged from those promoting a content-structure teaching approach to those trying to achieve the objectives of scientific literacy through general education objectives, process skills and the acquisition of applicable knowledge.

Epistemological Beliefs

Focus is on the process of learning. The range is between receptive and constructivist learning.

\section{Beliefs about Teaching Style}

The focus is on the student- or teachercenteredness within the class. Extrapolation of all activities seems to be reasonable, but the testing tool concentrates on single aspects to indicate whether or not the teacher tries to focus pupils' attention on him.

Beliefs about the Value of Learning Scientific Knowledge

The focus is on the importance of the learned knowledge. Answers range from knowledge being value-free to knowledge being important for functioning in society.

Beliefs about the Nature of School Science Knowledge

Focus is on the characteristics of the knowledge. The range stretches from objectivistic to post-positivistic viewpoints. 